\title{
6 \\ Implementasi Metode Promethee dan Borda Dalam Sistem Pendukung Keputusan Pemilihan Lokasi Pembukaan Cabang Baru Bank
}

\author{
Dyah Apriliani $^{\mathrm{a},{ }^{*},}$ Kusworo Adi ${ }^{\mathrm{b}}$, Rahmat Gernowo ${ }^{\mathrm{c}}$ \\ ${ }^{\text {a } U n i v e r s i t a s ~ A h m a d ~ D a h l a n ~}$ \\ ${ }^{\text {bc }}$ Program Studi Fisika, Fakultas Sains dan Matematika, Universitas Diponegoro
}

Naskah Diterima : 23 Mei 2015; Diterima Publikasi : 23 Juli 2015

\begin{abstract}
The selection of a new branch bank location is crucial to the success of the bank in the future. The object of this research is BMT Muamalat. PROMETHEE method is used to manage individual decision of each decision makers, while Borda method is used to manage group decisions of PROMETHEE method in ranking the results. The use of these two methods is one solution to produce a more objective group decision. Ranked of alternative location have appropriated with the opening rules of the new branches of BMT Muamalat. As for the variables in this study are criminality, facilities and infrastructures, per capita income, economic growth, population, and the number of competitors around the alternative location of a new branch. The results of this research is Banyuputih as the best alternative location.
\end{abstract}

Keywords: Decision support systems; Choice of location of the bank; PROMETHEE; Borda

\begin{abstract}
Abstrak
Pemilihan lokasi cabang baru bank merupakan hal yang sangat menentukan terhadap keberhasilan bank tersebut di masa yang akan datang. Objek dalam penelitian ini adalah BMT Muamalat. Metode PROMETHEE digunakan untuk mengelola keputusan individu dari masing-masing pembuat keputusan, sedangkan metoda Borda digunakan untuk mengelola keputusan kelompok hasil perankingan metode PROMETHEE. Penggunaan kedua metode ini merupakan salah satu solusi untuk menghasilkan keputusan kelompok yang lebih objekif. Perankingan alternatif lokasi ini telah sesuai dengan aturan pembukaan cabang baru dari BMT Muamalat. Adapun variabel dalam penelitian ini adalah kriminalitas, sarana dan prasarana, pendapatan perkapita, pertumbuhan ekonomi, jumlah penduduk dan jumlah bank di sekitar alternatif lokasi pembukaan cabang baru bank. Hasil yang diperoleh dari penelitian ini yaitu Banyuputih sebagai alternatif lokasi terbaik.
\end{abstract}

Kata Kunci: Sistem pendukung keputusan; Pemilihan lokasi bank; PROMETHEE, Borda

\section{Pendahuluan}

Dalam dunia perbankan sering dihadapkan pada permasalahan pemilihan lokasi pembukaan cabang baru. Pemilihan lokasi merupakan suatu tahapan awal dalam pengembangan dan relokasi bisnis suatu perusahaan (Rikalovic et al., 2014). Pemilihan lokasi yang tepat dapat menentukan keberhasilan bank tersebut di masa yang akan datang. Karena itu, diperlukan sebuah pengambilan keputusan dalam memilih alternatif yang ada ataupun yang disediakan (Boufounou, 1995). Mengambil keputusan adalah salah satu bagian dari kegiatan manusia yang dapat dilakukan dalam kehidupan sehari-hari. Dalam proses pengambilan keputusan pembukaan cabang baru ini dilakukan oleh beberapa orang yang

\footnotetext{
*) Penulis korespondensi: dyah.apriliani@yahoo.com
}

berperan penting dalam bank tersebut. Hal tersebut dilakukan guna mendapatkan lokasi yang benarbenar tepat untuk pembukaan cabang baru bank.

Penentuan lokasi cabang baru bank ini memerlukan analisis mengenai kriteria-kriteria yang akan digunakan oleh para pembuat keputusan. Hal ini disebabkan proses pemilihan lokasi pembukaan cabang baru bank memiliki beberapa kriteria (multikriteria) lokasi yang akan dipilih. Kriteriakriteria tersebut terkait dengan faktor-faktor yang mendukung kelancaran dan kemajuan bank tersebut. Adapun kriteria lokasi yang biasa digunakan dalam sistem pendukung keputusan pembukaan cabang baru bank pada umumnya merupakan daerah kawasan industri yang memiliki tingkat perekonomian yang lebih tinggi dengan melihat pendapatan perkapita 
daerah, tingkat kriminalitas, sarana dan prasarana, jumlah bank yang tersedia, jumah penduduk, serta kehidupan sosial ekonomi penduduk sekitar yang akan dijadikan sebagai lokasi pembukaan cabang baru bank. (Boufounou, 1995).

Sistem pendukung keputusan adalah sistem yang digunakan untuk membantu dalam penyelesaian masalah dan dukungan keputusan. Dalam penelitian ini digunakan metode PROMETHEE dan Borda. Metode Preference Ranking Organisational Method for Enrichment Evaluation (PROMETHEE) merupakan metode penentuan urutan atau prioritas dalam analisis multikriteria yang menawarkan cara yang fleksibel dan sederhana kepada user (pengambil keputusan) untuk menganalisis masalah-masalah multikriteria (Doumpos et al., 2010). Dalam penerapan kehidupan sehari-hari metode PROMETHEE sering digunakan dalam beberapa aspek, diantaranya bidang pendidikan, pertanian, pemerintahan, dan olahraga (Behzadian et al., 2010). Dalam kasus pemilihan lokasi pembukaan cabang baru Bank ini metode PROMETHEE digunakan untuk melakukan pengambilan keputusan individu. Pengambilan keputusan individu dilakukan oleh masing-masing pembuat keputusan dengan memberikan input yang berupa nilai atau pembobotan terhadap kriteria-kriteria yang digunakan. Metode PROMETHEE digunakan dalam penelitian ini karena metode ini cukup baik dalam memperhitungkan karakteristik dari data serta menyediakan banyak fungsi yang dapat mengakomodasi berbagai karakteristik data (Akafpour et al., 2013). Metode Borda menggunakan perhitungan preferensial untuk melakukan perankingan terhadap input yang diberikan oleh pembuat keputusan yang memiliki lebih dari satu alternatif (Klamler, 2004). Metode Borda dalam penelitian ini digunakan untuk mengakomodasi keputusan masing-masing pembuat keputusan yang dihasilkan dari perhitungan metode PROMETHEE. Perhitungan dengan metode borda menggunakan bobot pada setiap perangkingan masing-masing pembuat keputusan. Alternatif pilihan dengan posisi peringkat atas yang dihasilkan masing-masing pembuat keputusan diberi nilai yang lebih tinggi dibandingkan dengan peringkat dibawahnya. Dengan menggunakan metode tersebut, maka keputusan yang dihasilkan lebih bijaksana tergantung pada peringkat yang asli (Wu, 2011).

Dalam penelitian ini memerlukan beberapa kriteria mengenai lokasi yang akan dipilih oleh beberapa pihak yang terlibat sebagai alternatif pilihan lokasi pembukaan cabang baru bank. Oleh karena itu, diperlukan suatu sistem pendukung keputusan kelompok untuk menentukan lokasi pembukaan cabang baru bank sehingga keputusan yang dihasilkan merupakan keputusan yang tepat dan bijaksana. Berdasarkan penjelasan diatas maka akan dikembangkan sebuah sistem pendukung keputusan kelompok dengan menggunakan metode PROMETHEE dan Borda untuk pemilihan lokasi pembukaan cabang baru bank.

\section{Kerangka Teori}

\subsection{Group Desicion Support System (GDSS)}

Group Decision Support System (GDSS) atau biasa dikenal dengan nama sistem pendukung keputusan kelompok dikembangkan untuk memberikan bantuan dalam pengambilan keputusan kelompok (Brans,1986). Komponen dari GDSS ini terdiri dari orang (penilai/pembuat keputusan), dan prosedur. Prosedur ada GDSS dibedakan menjadi tiga tahapan yaitu:

a. Penentuan alternatif dan kriteria

b. Evaluasi oleh masing-masing pembuat keputusan

c. Evaluasi kelompok

\subsection{PROMETHEE}

Metode PROMETHEE (Preference Ranking Organization Method for Enrichment Evaluation) adalah suatu metode penentuan urutan atau prioritas dalam analisis multikriteria yang menawarkan cara yang fleksibel dan sederhana kepada user (pembuat keputusan) untuk menganalisis masalah-masalah multikriteria (Little, 1970).

Tujuan PROMETHEE yaitu memudahkan proses pengambilan keputusan dengan cara mengelompokkan tipe keputusan menjadi enam fungsi kriteria (preferensi). Adapun fungsi kreteria tersebut adalah :

a. Kriteria preferensi Umum

b. Kriteria preferensi Quasi

c. Kriteria preferensi Linier

d. Kriteria preferensi Level

e. Kriteria preferensi Linier dan area yang tidak berbeda

f. Kriteria Gaussian

Dari 6 tipe preferensi tersebut yang digunakan dalam penelitian ini adalah tipe preferensi yang ketiga, yaitu tipe preferensi linear. Gambar 2.1 adalah gambar dari tipe preferensi linear.

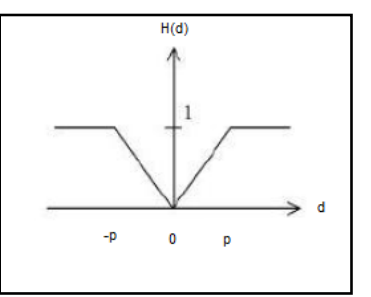

Gambar 1. Tipe preferensi linier

Selama nilai selisih lebih rendah dari $\mathrm{x}$, maka preferensi dari pembuat keputusan meningkat secara linier dengan nilai $m$ Jika nilai $x$ lebih besar dibandingkan dengan nilai $\mathrm{m}$, maka terjadi preferensi mutlak. 


$$
p(x)=\left\{\begin{array}{c}
x / m \text { jika } x \leq m \\
1 \text { jika } x>m
\end{array}\right.
$$

Dimana

$x=$ selisih nilai kriteria $(x=f(a)-f(b))$

Adapun langkah-langkah perhitungan dengan metode PROMETHEE adalah sebagai berikut:

a. Menentukan beberapa alternatif.

b. Menentukan beberapa kriteria.

c. Menetukan bobot kriteria.

d. Menentukan kaidah penilaian, dimana kaidah penilaian ini memiliki dua tipe yaitu: minimum atau maksimum.

e. Menentukan tipe preferensi untuk setiap kriteria yang didasarkan pada data dan pertimbangan dari pembuat keputusan. Tipe preferensi tersebut adalah Usual, Quasi, Linear, Linear Quasi, dan Gaussian.

f. Menghitung indeks preferensi $\pi(a, b)=\frac{1}{k} \sum_{h=1}^{k} P_{h}(a, b)$

g. Perhitungan Leaving Flow, Entering Flow dan Net Flow

$$
\begin{aligned}
& \phi^{+}(a)=\sum_{x \in K} \pi(a, x) \\
& \phi^{-}(a)=\sum_{x \in K} \pi(x, a) \\
& \phi(a)=\phi^{+}(a)-\phi^{-}(a)
\end{aligned}
$$

h. Hasil pengurutan hasil dari perankingan (Brans et al., 1985).

\subsection{Borda}

Metode Borda ditemukan oleh Jean-Charles de Borda pada abad ke 18. Metode Borda adalah metode yang dipakai untuk menentapkan peringkat pada pengambilan keputusan secara preferensial. Metode borda digunakan pada pengambilan keputusan kelompok untuk melakukan perangkingan terhadap kandidat yang disusun berdasarkan pilihan masingmasing pembuat keputusan (Zarghami, 2011). Metode borda merupakan salah satu yang dapat digunakan untuk mengakomodasi hasil para pembuat keputusan. Perhitungan pada borda menggunakan bobot pada setiap posisi rangking yang dihasilkan oleh masing-masing pembuat keputusan. Alternatif pilihan dengan posisi peringkat atas diberi nilai lebih tinggi dengan kandidat pada posisi peringkat berikutnya dalam suatu perbandingan berpasangan. Perhitungan metode borda sebagai metode pengambilan keputusan kelompok untuk menentukan lokasi terbaik pembukaan cabang baru bank berdasarkan preferensi kelompok pembuat keputusan. Output proses perhitungan menggunakan metode PROMETHEE berupa alternatif lokasi teranking menjadi input proses Borda. Alternatif lokasi diberikan poin $\mathrm{N}-1$ untuk setiap tingkatan ranking. Poin terbesar diperoleh alternatif lokasi dengan ranking teratas paling banyak dari kelompok pembuat keputusan (Wu, 2011).

\subsection{Kriteria Lokasi}

Kriteria yang digunakan dalam sistem pendukung keputusan pembukaan cabang baru bank ini yaitu: tingkat kriminalitas, sarana dan prasarana, pendapatan perkapita, pertumbuhan ekonomi, jumlah penduduk dan jumlah bank yang ada di alternatif lokasi pembukaan cabang baru bank (Pusat Komunikasi Ekonomi Syariah, 2008). Adapun alternatif lokasi yang digunakan dalam penelitian ini yaitu: $\mathrm{A}_{1}=$ Bawang, $\mathrm{A}_{2}=$ Reban, $\mathrm{A}_{3}=$ Subah, $\mathrm{A}_{4}=$ Bandar, $\mathrm{A}_{5}=$ Banyuputih.

\section{Metodologi}

\subsection{Prosedur Penelitian}

Ada beberapa tahap prosedur penelitian yang akan dilakukan dalam penelitian ini, yaitu: pendefinisian masalah, pengumpulan data, identifikasi dan pengolahan data, perancangan sistem, implementasi sistem, dan pengujian sistem. Prosedur penelitian dapat kita lihat dalam Gambar 2.

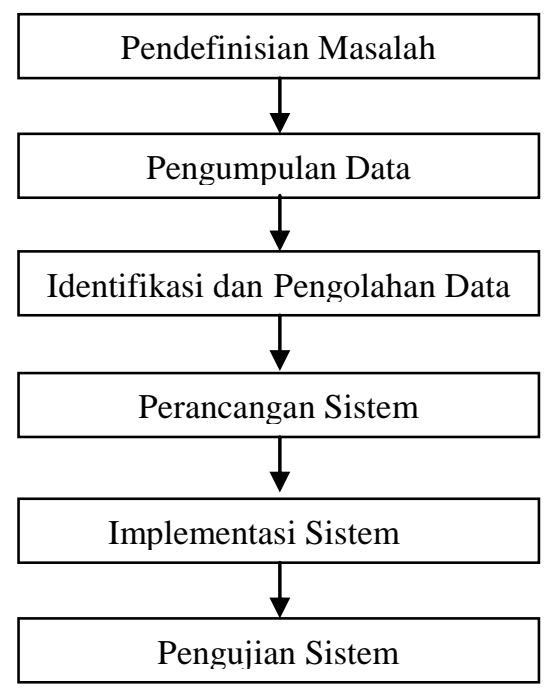

Gambar 2. Prosedur Penelitian

Adapun tahap-tahap tersebut dapat dijelaskan sebagai berikut :

a. Pendefinisian masalah

Sebelum sistem pendukung keputusan dibangun, permasalahan dalam penelitian harus didefinisikan dengan tepat sehingga hasil yang diperoleh sesuai dengan masalah yang dihadapi.

b. Pengunpulan data

Pengumpulan data diperoleh dengan melakukan studi pustaka tentang metode PROMETHEE dan Borda yang digunakan dalam penelitian, serta variable dan kriteria penentu pembukaan cabang baru suatu Bank dari beberapa literatur seperti: 
jurnal, buku dan sumber ilmiah lainnya yang berhubungan dan relevan dengan penelitian.

c. Identifikasi dan pengolahan data

Pada tahapan ini akan dilakukan identifikasi dan pengolahan terhadap data yang telah diperoleh.

d. Analisis dan Perancangan Sistem

Melakukan analisis dan perancangan sistem sesuai dengan masalah yang telah diidentifikasi. Metode Promethee digunakan untuk menghasilkan perangkingan lokasi secara individu oleh para pembuat keputusan dan metode Borda untuk pemilihan lokasi cabang Bank terbaik secara kelompok.

e. Implementasi Sistem

Pada tahap ini akan dilakukan pengimplementasian sistem sesuai dengan konsep yang telah disusun pada tahap sebelumnya.

f. Pengujian Sistem

Setelah proses imlementasi selesai selanjutnya dilakukan pengujian terhadap sistem yang telah dibuat. Pengujian sistem dilakukan untuk mengetahui apakah sistem yang dibuat sesuai dengan hasil yang diharapkan atau tidak. Pengujian dilakukan dalam bentuk dua tahap, yaitu pengujian terhadap performa sistem dan pengujian terhadap proses perhitungan analisa. Proses validasi performa sistem dilakukan dengan cara melihat fakta lapangan atau history dengan hasil keluaran dari sistem.

\section{Hasil dan Pembahasan}

\subsection{Hasil penelitian}

Aplikasi yang dibuat dapat digunakan oleh user menggunakan browser. Adapun Tampilan dari sistem yang dapat dilihat pada Gambar 3.

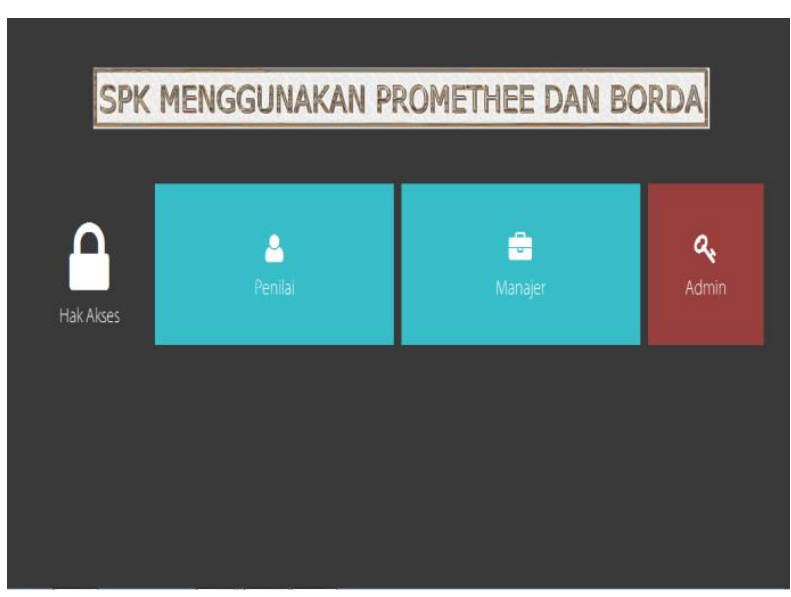

Gambar 3. Tampilan Utama Aplikasi

Dari tampilan tersebut dapat dilihat adanya perbedaan hak akses, penilai merupakan pembuat keputusan yang bertugas untuk memberikan penilaian terhadap kriteria dari masing-masing alternatif lokasi. Selanjutnya penilaian tersebut diproses menggunakan metode PROMETHEE, sehingga menghasilkan keputusan individu. Manager bertugas untuk mengelola hasil keputusan individu menjadi keputusan kelompok menggunakan metode Borda. Hasil dari perangkingan masing-masing pembuat keputusan selanjutnya menjadi masukan untuk proses perhitungan menggunakan metode Borda. Sedangkan admin bertugas sebagai pengelola dari sistem yang melakukan proses tambah, ubah dan juga simpan.

Kriteria yang digunakan dalam penelitian ini meliputi: kriminalitas, sarana dan prasarana, pendapatan perkapita, pertumbuhan ekonomi, jumlah penduduk dan jumlah bank yang tersedia di masingmasing alternatif lokasi pembukaan cabang Bank baru. Pada Tabel 1 dapat dilihat hasil penilaian yang diberikan oleh pembuat keputusan pertama (Penilai pertama).

Tabel 1. Tabel nilai kriperia penilai pertama

\begin{tabular}{clrrrrr}
\hline \multirow{2}{*}{ No } & \multicolumn{1}{c}{ Kriteria } & \multicolumn{5}{c}{ Skor kriteria } \\
\cline { 3 - 7 } & & A1 & A2 & A3 & A4 & A5 \\
\hline 1. & Kriminalitas & 45 & 70 & 50 & 75 & 90 \\
2. & Sarana dan Prasarana & 20 & 40 & 23 & 20 & 60 \\
3. & Perdapatan perkapita & 60 & 77 & 65 & 60 & 80 \\
4. & Pertumbuhan ekonomi & 15 & 40 & 20 & 45 & 60 \\
5. & Jumlah penduduk & 65 & 40 & 60 & 40 & 70 \\
6. & Jumlah bank & 35 & 25 & 20 & 30 & 40 \\
\hline
\end{tabular}

Tabel 2 merupakan penilaian yang diberikan oleh pembuat keputusan kedua (Penilai kedua).

Tabel 2. Tabel nilai kriperia penilai kedua

\begin{tabular}{clrrrrr}
\hline \multirow{2}{*}{ No } & \multicolumn{1}{c}{ Kriteria } & \multicolumn{5}{c}{ Skor kriteria } \\
\cline { 3 - 7 } & & A1 & A2 & A3 & A4 & A5 \\
\hline 1. & Kriminalitas & 30 & 53 & 50 & 51 & 80 \\
2. & Sarana dan Prasarana & 23 & 45 & 25 & 23 & 70 \\
3. & Perdapatan perkapita & 70 & 80 & 70 & 65 & 85 \\
4. & Pertumbuhan ekonomi & 20 & 45 & 23 & 48 & 70 \\
5. & Jumlah penduduk & 70 & 45 & 65 & 40 & 73 \\
6. & Jumlah bank & 35 & 41 & 20 & 42 & 40 \\
\hline
\end{tabular}

Tabel 3 merupakan penilaian yang diberikan oleh pembuat keputusan ketiga (Penilai ketiga).

Tabel 3. Tabel nilai kriperia penilai ketiga

\begin{tabular}{llrrrrr}
\hline \multirow{2}{*}{ No } & \multicolumn{1}{c}{ Kriteria } & \multicolumn{5}{c}{ Skor kriteria } \\
\cline { 3 - 7 } & & A1 & A2 & A3 & A4 & A5 \\
\hline 1. & Kriminalitas & 50 & 60 & 40 & 50 & 70 \\
2. & Sarana dan Prasarana & 25 & 50 & 30 & 25 & 75 \\
3. & Perdapatan perkapita & 75 & 85 & 73 & 65 & 90 \\
4. & Pertumbuhan ekonomi & 25 & 50 & 25 & 50 & 90 \\
5. & Jumlah penduduk & 75 & 50 & 70 & 45 & 75 \\
6. & Jumlah bank & 45 & 50 & 25 & 45 & 50 \\
\hline
\end{tabular}

Pada penelitian ini metode PROMETHEE digunakan dalam menentukan prioritas lokasi pembukaan cabang baru bank. Setiap kriteria yang dimiliki suatu alternatif lokasi akan dibandingkan dengan kriteria dari alternatif lokasi lainnya. Adapun tipe preferensi yang digunakan adalah tipe preferensi linier. Berikut ini adalah studi kasus untuk penilai pertama dalam menentukan lokasi pembukaan 
cabang baru bank menggunakan metode PROMETHEE.

Tabel 4. Data perhitungan PROMETHEE

\begin{tabular}{|c|c|c|c|c|c|c|c|c|c|c|c|}
\hline \multirow{2}{*}{ Kriteria } & \multirow{2}{*}{ Bobot } & \multirow{2}{*}{ Kaidah } & \multirow{2}{*}{ a1 } & \multirow{2}{*}{ a2 } & \multirow{2}{*}{ a3 } & \multirow{2}{*}{24 a } & \multirow{2}{*}{25} & \multirow{2}{*}{ Tipe } & \multicolumn{3}{|c|}{ Parameter } \\
\hline & & & & & & & & & & & P2 \\
\hline k1 & & $1 \max$ & 45 & 70 & 50 & 75 & 90 & & $m$ & 50 & \\
\hline$k 2$ & & 1 max & 20 & 40 & 23 & 20 & 60 & & $m$ & 50 & \\
\hline$K^{\prime}$ & & $1 \max$ & 60 & 77 & 65 & 60 & 80 & & $m$ & 50 & \\
\hline k4 & & $1 \max$ & 15 & 40 & 20 & 45 & 60 & & $m$ & 50 & \\
\hline$k$ & & 1 max & 65 & 40 & 60 & 40 & 70 & & $m$ & 50 & \\
\hline & & 1 max & 35 & 25 & 20 & 30 & 40 & & $m$ & 50 & \\
\hline
\end{tabular}

Berdasarkan data tersebut, selanjutnya dilakukan perhitungan menggunakan metode PROMETHEE. Perhitungan tersebut menghasilkan nilai indeks preferensi. Pada Tabel 5 dapat dilihat hasil nilai indeks preferensi penilai pertama dari masing-masing alternatif lokasi.

Tabel 5. Nilai indeks preferensi

\begin{tabular}{|l|r|r|r|r|r|}
\multicolumn{7}{|c|}{ Tabel Nilai $\pi\left(a_{i}, a_{j}\right)$} \\
\hline & \multicolumn{1}{l|l}{ a1 } & \multicolumn{1}{c|}{ a2 } & \multicolumn{1}{c|}{ a3 } & \multicolumn{1}{c|}{ a4 } & \multicolumn{1}{c|}{ a5 } \\
\hline a1 & 0 & 0,1167 & 0,0667 & 0,1000 & 0 \\
\hline a2 & 0,2900 & 0 & 0,2467 & 0,1233 & 0 \\
\hline a3 & 0,0600 & 0,0667 & 0 & 0,0933 & 0 \\
\hline a4 & 0,2000 & 0,0500 & 0,2000 & 0 & 0 \\
\hline a5 & 0,5333 & 0,3600 & 0,5400 & 0,4333 & 0 \\
\hline
\end{tabular}

Dari nilai indeks preferensi diatas maka dapat diperoleh nilai leavingflow, enteringflow, dan netflow. Nilai tersebut dapat dilihat pada Tabel 6.

Tabel 6. Nilai leavingflow, enteringflow, dan netflow

\begin{tabular}{|c|c|c|c|c|c|c|}
\hline \multicolumn{7}{|c|}{ Data Preorder $\Phi^{+}$dan $\Phi^{-}$} \\
\hline $\begin{array}{c}\text { Kode } \\
\text { Alternati }\end{array}$ & $\Phi^{+}$ & $\Phi$ & $\Phi$ & $\begin{array}{l}\text { Ranking } \\
\text { Leaving }\end{array}$ & $\begin{array}{l}\text { Ranking } \\
\text { Entering }\end{array}$ & $\begin{array}{c}\text { Ranking Net } \\
\text { Flow }\end{array}$ \\
\hline a1 & 0,2833 & 1,0833 & $-0,8000$ & 4 & 1 & 4 \\
\hline a2 & 0,6600 & 0,5933 & 0,0667 & 2 & 4 & 2 \\
\hline a3 & 0,2200 & 1,0533 & $-0,8333$ & 5 & 2 & 5 \\
\hline a4 & 0,4500 & 0,7500 & $-0,3000$ & 3 & 3 & 3 \\
\hline a5 & 1,8667 & 0 & 1,8667 & 1 & 5 & 1 \\
\hline
\end{tabular}

Proses perankingan penentuan alternatif lokasi pembukaan cabang baru bank diurutkan berdasarkan nilai netflow terbesar sampai terkecil. Dari Tabel 6 diatas dapat dilihat bahwa lokasi A5 merupakan lokasi yang paling berpotensi untuk dilakukan pembukaan cabang baru bank kemudian setelah itu A2, A4, A1, dan yang terakhir A3. Dengan cara yang sama data untuk penilai kedua setelah dilakukan pemrosesan perhitungan PROMETHEE menghasilkan lokasi A5 adalah lokasi yang paling berpotersi kemudian A2, A4, A3, dan terakhir A1. Sedangkan untuk penilai ketiga mengasilkan perankingan lokasi A5 sebagai lokasi yang paling berpotensi, kemudian selanjutnya lokasi A2, A1, A4, dan A3.

Dari hasil keputusan individu yang dihasilkan oleh masing-masing pembuat keputusan, selanjutnya dilakukan pemrosesan menggunakan metode borda. Perhitungan Borda ini digunakan untuk mengelola keputusan kelompok dari perankingan yang dihasilkan oleh masing-masing penilai sehingga keputusan yang dihasilkan lebih objektif. Hasil perangkingan dari masing-masing penilai dapat dilihat pada Tabel 7.

Tabel 7. Nilai Perankingan Masing-Masing Penilai

\begin{tabular}{|l|r|r|r|}
\cline { 2 - 4 } \multicolumn{1}{c|}{ Alternatif } & \multicolumn{3}{|c|}{ Ranking PROMETHEE } \\
\cline { 2 - 4 } & Penilai 1 & Penilai 2 & Penilai 3 \\
\hline A1 & 4 & 5 & 3 \\
\hline A3 & 2 & 2 & 2 \\
\hline A4 & 5 & 4 & 5 \\
\hline A5 & 3 & 3 & 4 \\
\hline
\end{tabular}

Dari perankingan diatas selanjutnya dilakukan perhitungan metode Borda. Perhitungan Borda ini dilakukan dengan pemberian bobot dimana dengan ranking pertama memperoleh nilai $\mathrm{n}-1$, dimana $\mathrm{n}$ adalah jumlah alternatif. Tabel 8 merupakan hasil dari perhitungan Borda yang dihasilkan.

Tabel 8. Nilai perankingan borda

\begin{tabular}{|l|r|r|}
\hline \multirow{2}{*}{ Alternatif } & \multicolumn{2}{|c|}{ Borda } \\
\cline { 2 - 3 } A1 & Nilai & Ranking \\
\hline A2 & 3 & 4 \\
\hline A3 & 9 & 2 \\
\hline A4 & 1 & 5 \\
\hline A5 & 5 & 3 \\
\hline
\end{tabular}

Dari hasil tersebut dapat dilihat bahwa perangkingan keputusan kelompok menggunakan metode borda menghasilkan lokasi A5 sebagai prioritas utama, kemudian A2, A4, A1 dan A3.

\section{Kesimpulan}

Pada penelitian ini telah dibangun sistem pendukung keputusan untuk pemilihan lokasi pembukaan cabang baru bank menggunakan metode PROMETHEE dan Borda. Sistem yang dibuat menghasilkan keluaran yang sama dengan perhitungan manual dan kenyataan data di lapangan.

Masing-masing pembuat keputusan menghasilkan urutan perankingan menggunakan metode PROMETHEE yang berbeda, yang selanjutnya diolah menggunakan metode Borda sehingga hasil perankingan akhir yang diperoleh merupakan hasil keputusan kelompok. Akan tetapi keputusan untuk 
pembukaan lokasi tetap sepenuhnya di tangan manajer.

Hasil keluaran menunjukkan bahwa alternatif lokasi yang memperoleh ranking tertinggi adalah di Banyuputih, namun di daerah tersebut telah di buka lokasi BMT Muamalat pada tahun lalu. Penelitian ini hanya membuktikan bahwa keluaran dari sistem yang di buat menghasilkan perankingan yang sesuai untuk rekomendasi lokasi pembukaan cabang baru bank. Oleh karena itu aplikasi dalam penelitian ini dapat digunakan untuk menentukan rekomendasi lokasi pembukaan cabang selanjutnya.

\section{Daftar Pustaka}

Akafpour, A. and Hamidi, N., 2013. Improved techniques PROMETHEE preference for the changed conditions. Technical Journal of Engineering and Applied Sciences, 3681-3687.

Behzadiana, M., Kazemzadeh,R,B., Albadvi, A. and Aghdasi, M., 2010. PROMETHEE: A comprehensive literature review on methodologies and applications. European Journal of Operational Research 200, 198-215.

Boufounou, P.V., 1995. Theory and methodology evaluating bank branch location and performance: A case study. European Journal of Operational Research 87, 389-402.
Brans, J.P. and Vinke, P.H., 1985. A preference ranking organisation method: (The PROMETHEE method for multiple criteria decision-making). Management Science, vol. 31, no. 6 (jun., 1985), pp. 647-656

Brans, J.P., Vincke, P. H. and Mareschal, B., 1986. How to select and how to rank projects : the PROMETHEE method. European Journal of Operational Research 24, 228-238.

Doumpos, M. and Zopounidis, C., 2010. A multicriteria decision support system for bank rating. Decision Support Systems, 50, 55-63.

Klamler, C., 2004. The dodgson ranking and the Borda count: a binary comparison. Mathematical Social Sciences, 48, 103- 108.

Little, J.D.C., 1970. Models and managers : the concept op a decision calculus. Management Science Vol 16 No.8.

Rikalovic, A.,, Cosic, I. and Lazarevic, D., 2014. GIS Based Multi-Criteria Analysis for Industrial Site Selection, Procedia Engineering, 69, 1054 -1063 .

Wu, W.W., 2011. Beyond travel \& tourism competitiveness ranking using DEA, GST, ANN and Borda count. Expert Systems with Applications, 38, 12974-12982.

Zarghami, M., 2011, Soft computing of the Borda count by fuzzy linguistic quantifiers. Applied Soft Computing 11, 1067-1073. 